\title{
MILITANT AND LIBERAL ISLAM The Unwanted Twin Children of Modernization - An Indonesian Experience ${ }^{1}$
}

\author{
Achmad Muniid \\ Temple University, Philadelphia, PA
}

\begin{abstract}
This paper examines Islamic militancy and liberalism as particular phenomena resulting from a complex interplay between Islam and modernity within the context of Indonesia. The development of both groups is highly conditioned and shaped by modernization. The difference in backgrounds leads further to different directions in understanding and practicing Islam among both groups. Nevertheless, the present day contest between the liberals and the militants over the 'right' place of Islam in Indonesia has deep roots in the past and reflects Muslims' theological, historical, socio-political and intellectual struggle before modernity. Accelerated by the huge modernization project, the emergence of militancy and liberalism articulates the dynamics of Indonesian Muslims' negotiation with Islam, the modern world, and their social reality. This paper examines the dialectical interaction between the two different groups of Muslims, in response particularly to the relationship between Islam and modernity.
\end{abstract}

Keywords: Militant Islam, liberal Islam, modernization, conflict.

\section{Introduction}

Perhaps due to the strong influence of Sufism in its earliest period, Islam in Indonesia has been considered as being ambiguous. On the

\footnotetext{
1 The earlier version of this paper was presented at the AMSS $34^{\text {th }}$ Annual Conference "Muslims and Islam in the Chaotic Modern World: Relations of Muslims among Themselves and with others" co-sponsored by Temple University, Philadelphia, PA, September 30 - October 2, 2005.
} 
one hand, Indonesia Islam is generally claimed to have had a tolerant and inclusive face. ${ }^{2}$ Historically embedded in a pluralistic society, Indonesian Muslims are known for their open-mindedness towards any 'wisdom' from outside worlds, including those of other world religious traditions, indigenous systems of beliefs and modern ideologies. The history of the nine Muslim saints (wali songo) in Java from an earlier period and the Islamic thought reform by contemporary figures such as Nurcholish Madjid and Abdurrahman Wahid aptly illustrates this perspective. Many people even believe that because of these tolerant and inclusive characteristics, Indonesian Muslims could play a leading role in the future.

On the other hand, viewed from a different perspective, Islam in Indonesia is frequently believed as suffering from deep syncretism. In this way, Indonesian Muslims' practices and understanding of Islam are seen as less correct or even incorrect and thus in need of fundamental correction. ${ }^{3}$ Not surprisingly, starting as early as the $19^{\text {th }}$ century there have been movements of purification that purported to instill 'correct' Islam in the country. ${ }^{4}$ Without this due correction, as the purificationists' assumption goes, Indonesian Muslims would be just as useless as foam on an ocean's surface, despite the fact that Indonesia has the largest population of Muslims amongst all of the Muslim countries. They are, therefore, frequently ignored.

In fact, this purification or 'correction' movement eventually results in tension, even conflict amongst people. Some people have fought for the 'purification' idea, fighting against their fellow Muslims, and some others have advocated their traditional values. Social conflict in the Paderi movement, which took place between kaum tua (the old group) and kaum muda (the young group) in West Sumatra during the Dutch colonial era, is a clear example. ${ }^{5}$

\footnotetext{
2 Robert W. Hefner, Civil Islam: Muslim and Democratization in Indonesia (Princeton and Oxford: Princeton University Press, 2000), p. 14.

${ }^{3}$ Ibid., p. 15.

${ }^{4}$ Karel A. Steenbrink, Beberapa Aspek tentang Islam di Indonesia Abad ke-19 Jakarta: Bulan Bintang, 1984), p. 33.

5 William R. Roff, "Kaum Muda-Kaum Tua: Innovation and Reaction Amongst the Malay, 1900-1941," in Paper on Malayan History, edited by K.G. Tregonning (Singapore: Journal South East Asian History, 1962), pp. 162-192.
} 
In the same line, Muhammadiyah-now the second largest mass Muslim organization, with approximately 30 million members-was initially founded in 1912 for that very purpose of purification. ${ }^{6}$ Its popular slogan was "to fight against TBC" (tahayul, bid'ah, [c] burafatsociologically understood as superstition, 'unlawful' religious innovation and legend). Eventually, as a response from the 'traditionalist' group, whose Islam is supposed to suffer from syncretism, NU (Nahdlatul 'Ulama) was founded in 1926. It now claims to be the Indonesia's largest mass Muslim organization, with approximately 45 million members. Until recently, rivalry between these two organizations had been regular part of almost any public discourse amongst Muslims in the country. As will be clear in the next discussion, this long chain of tension between the 'purificationist' and the 'traditionalist' will contribute to the rising issue of militant versus liberal Islam in contemporary Indonesia.

To go further, when entering into political arena or dealing with political interests, often times the main goal of such "correction" groups is either to make Indonesia an Islamic state or to implement Islamic sharisath in public life through state sponsorship. The assumption is that, only when manifested through state power will Islam be practiced correctly by Indonesian Muslims. The longwinded pre-and post-1945 Independence debate over the Indonesian Constitution between the "nationalist" and the "shari athist" groups clearly describes the issue. ${ }^{7}$ One group, which included the NU as the representative of the traditionalist viewpoint, insisted that as multicultural and multi-religious society Indonesia should be based on Pancasila. ${ }^{8}$ Another group, comprising such 'purificationist' groups as

\footnotetext{
${ }^{6}$ James L. Peacock, Purifying the Faith: The Mubammadijah Movement in Indonesian Islam (Menlo Park, California: The Benjamin/Cummings Publishing Company, 1978).

${ }^{7}$ About the debate, read Ahmad Syafi'i Ma'arif, "Islam as the Basis of State: A Study of the Islamic Political Ideas as Reflected in the Constituent Assembly Debate in Indonesia," Unpublished PhD dissertation at Ohio University, Athens, 1982.

8 Pancasila, "The Five Pillars", is the Indonesian state ideology, consisting of: Belief in One Supreme God, Justice and civility among the people, Unity of Indonesia, Democracy through deliberations and consensus among representatives, and Social justice for all. These Five Principles are claimed as common platform among the elements of Indonesian society.
} 
Persis and Masyumi, insisted on making Islam the foundation of the state. $^{9}$

Needless to say, neither traditionalism nor purificationism is a matter of genealogy, but of ideology. This arguments helps us to understand why, in certain circumstances, as in the case of contemporary Indonesia, a similar group, but with different motives and orientation, belonging to the 'purificationists' might come from a very different background. What I am referring to here is militant Islam. What makes the purificationist and the militant similar is a tendency to perceive Islam as a dividing line between them and 'others', assuming themselves to be superior as they claim to be the possessors of truth. Therefore, they are entitled to 'purify' or 'correct' others who, they believe, are inferior and 'false'. In fact, the so-called militant Muslims are usually those who want to practice Islam as literally and formally as possible. In addition, they believe that everyone else should be like them.

However, there is a fundamental distinction between the purificationist and the militant. Purificationists primarily orient their view inwardly into the Muslim community, while militants orient their view outwardly. For purificationists, the 'others' generally means other Muslims with a different understanding of Islam. Since their mission is to purify Islamic teachings, non-Muslims are not really their focus. For militants, the 'others' generally means non-Muslims. If the purificationist wants to 'correct' their fellow Muslims, the militant wants to 'correct' the whole world, or at least all those who are different from them. Understandably, awareness of the presence of the 'others' in the sense of non-Muslim or non-Islamic world view is fundamental here. In relation to the emergence of Islamic militancy in Indonesia, the aggressive and imperialistic modern Western world, as brought into the country by modernization projects in the name of "national development" is clearly among the strongest factors.

It is necessary, therefore, to look at the huge modernization projects of the Soeharto era as the background and possibly a determinant factor for the emergence of militant Muslims in Indonesia. To that end, Soeharto's policies, especially in politics, religion and

\footnotetext{
9 The various separatist movements on behalf of Islam in the earlier years after Independence, however, were not always related to this shari xhist group. Many were merely political discontents, using Islam as a mobilizing vehicle to recruit supporters.
} 
education will be carefully examined in detail. Interestingly, it was this same situation that provided a platform for the liberal Muslim group to flourish in the country. Certainly, international factors did play a significant role. However, due to the scope and limits of this paper, international factors are only assumed to have been implied through the modernization project that used the West as the model.

\section{On Behalf of Modernization, For the Sake of Power}

For Soeharto, Indonesia under Soekarno (1945-1965) was a nightmare. Soekarno merely led the Indonesians to busy themselves with foamy 'nonsensical big words' and slogans about revolution only to end up with severely protracted ideological conflicts. Skyrocketing prices, huge money inflation, massive poverty and serious political segregation were further consequences. Replacing Soekarno at the critical moment after a failed 1965 bloody military coup d'etat, Soeharto wanted not only to distinguish but also to disconnect himself from his predecessor. Fully backed up by the Indonesian army and supported by students who were frustrated by Soekarno's corrupt regime and by the middle class group, Soeharto aimed to make a 'fresh start' for Indonesia. Therefore, he called his era "New Order" in opposition to the previous one, which disparagingly he labeled the "Old Order".

For Soeharto, any ideological debate should be terminated to keep national unity and stability. Every potential and actual threat to "unity and stability" needed to be paralyzed. Consequently, accused of being the main actor of the 1965 coup, communism was prosecuted "to its very roots". ${ }^{10}$ Although Muslims played a major role in helping Seoharto to wipe out communism, disappointingly for many Muslim

\footnotetext{
10 Accused of being a proponent, member or having any kind of association with the Indonesian Communist Party (PKI), some 500 thousand people were killed, mostly by the Indonesian military, many others were put imprisoned without trial. In this extermination of communists, Muslims played a major role. A Nahdhatul Ulama (NU)-affiliation youth organization called GP Anshor was even directly involved in this massacre. Until today, the Law prohibiting communism in Indonesia is in effect.. An effort made by former President Abdurrahman Wahid to annul that Law, i.e TAP MPRS XXV/1966, only provoked wide criticism and disagreements from various parts. As a reconciliation effort made by younger members of NU, SYARIKAT (Santri untuk Advokasi Rakyat, Santri for People Advocacy) was founded in 2002 to handle human right issues especially among the so-called communist victims of 1965 tragedy in Indonesia.
} 
groups, in the end (political) Islam was perceived by Soeharto as equally dangerous as communism. Therefore, any form of Islamism was also exterminated. ${ }^{11}$ Everyone had to accept only Pancasila as the final national ideology. ${ }^{12}$ In order not to repeat the previous crisis, political activity was to be sterile and free from ideology..$^{13}$

In accordance with that, in 1973, Islamic political parties were forced to fuse into one political body, the Partai Persatuan Pembangunan (PPP, United Development Party). Moreover, none of the previous strong Muslim political leaders was allowed to play a

\begin{abstract}
${ }^{11}$ Since Muslims are a majority (85\%), debate has arisen on the place and role of Islam in the modern Indonesian nation state since Independence in 1945. Due to the emergency condition at that time, the debate was pending in the form of the most compromising document called "Jakarta Charter". During Soekarno's era this topic was repeated for some time and consumed a great deal of energy. Rebellions seeking an Islamic state for Indonesia, or part of its territory, even took place in certain areas. Impatient with the longwinded and time-consuming debate about the constitution, including the place of Islam in national life as a hottest topic, on July 5, 1959, finally Soekarno issued a decree by which he dissolved the parliament and named his government as 'Guided Democracy'. In 1963 Soekarno also dissolved Masyumi, a very influential Islamic party and the second largest one in 1955 election, giving as an excuse the involvement of its leader, M. Natsir, in PRRI rebellion to establish Islamic state in Sumatra. At that point, fair debate on the place and role of Islam in the modern Indonesian nation state was not properly finished. For the role of Islamic political party before Soeharto era, read Deliar Noer, Partai Islam di Pentas Nasional; Kisab dan Analisis Perekembangan Politik Indonesia, 1945-1965 (Bandung: Mizan, 2000). Now, wary of this historical experience, although most major Muslim groups, including NU and Muhammadiyah, agreed that Indonesia should not be an Islamic State, Soeharto believed that political Islam was a very potential threat to his power and he refused to open the slightest opportunity for them. With regard to Muslims' major role in helping the extermination of communism in 1965, Soeharto's hostile political attitude to Muslims in general has been perceived as betrayal and has resulted in long-lasting frustration.

12 During the formulation debate, as recorded in Jakarta Charter, the First Principle of Pancasila was followed by a clause reads: "with the obligation for adherents of Islam to practice Islamic law". Those "seven words" were finally removed, after longwinded and sometimes furious debate, for the sake of democracy. For debate on this issue during the earlier years of Indonesia, read B.J. Boland, The Struggle of Islam in Modern Indonesia (Leiden: The Hague-Martinus Nijhoff, 1971). On the role of Pancasila in contemporary Indonesia, read Douglas E. Ramage, Politics in Indonesia: Democracy, Islam and the Ideology of Tolerance (London and New York: Routledge, 1995).

${ }^{13}$ About the Muslim dilemma concerning the issue of Pancasila as the sole foundation, read M. Rusli Karim, Islam dan Konflik Politik Era Orde Baru (Yogyakarta: MW Mandala, 1992).
\end{abstract}


significant role both in political parties and social mass-based organizations. $^{14}$ Many Muslims called this situation the "depoliticization of Islam". ${ }^{15}$ In the same manner, Christian and other smaller political parties were forcibly fused into another political body; the Partai Demokrasi Indonesia (PDI, Indonesian Democratic Party). One only other political party was allowed to exist, namely Golkar, the government party that then became the ruling party for more than 30 years.

To prevent any political problems, participation of the people was limited to a minimum by a program called "floating mass". Also, in order to forestall any potential threat to Soeharto's political ascendancy, key persons of almost every organization were either to be appointed by Soeharto himself, or at least, politically accepted by the state. ${ }^{16}$ This policy was crafted, considering "national unity and stability" as the sine qua non for the success of national development project. With such a weak civil society exhausted for so long by political problems and economic depression, almost none of individuals or groups could be expected to control the state power. Therefore, the seeds of Soeharto's authoritarianism grew up rapidly and extensively.

Furthermore, the orientation of Indonesian national life during the Soeharto's period was the economy. Instead of debating over ideology and abstract words, people were encouraged to participate in concrete programs of national development called "Pelita" (Pembangunan Lima Tahun, Five-Yearly Development Program). If in the past Soekarno was very critical of capitalism and Western countries, Soeharto sought any possible opportunity for cooperation with them. Every door was opened to international monetary organizations such as the World Bank, Asian Development Bank (ADB), and International Monetary Fund (IMF). The reason for this was obvious: his ambitious national

\footnotetext{
14 Mohammad Roem, a former Prime Minister and chairman of Masyumi, the most influential Islamic party during Soekarno era, was banned from any political activity by Soeharto. In one funeral ceremony, Soeharto even prohibited him from praying together with other funeral ceremony participants.

${ }^{15}$ Karim, Islam dan Konflik Politik.

16 Wahid, later the fourth president, was perhaps among those unwanted people due to his frequent public criticisms of Soeharto. When Wahid was three times re-elected as chairman of NU (1984-1999), Soeharto tried any effort to topple him, but without any success. His case is exceptional, though.
} 
development project needed a lot of money. Needless to say, Soeharto's developmentalism policy, calling for continued linear progress, expansion of production, supremacy of technology, and rational design of the social order, was a classic version of what James C. Scott called "high modernism". ${ }^{17}$

In order to fully guarantee the success of his national development and secure his power, Soeharto not only tightly controlled political life but also designed and applied huge social engineering by mapping out, structuralizing and rationalizing every aspect of social life. For example, each group of people based either on age, sex, profession or motive was provided with a particular organization that was structurally centralized. Any existing organization for the same category or purpose was to be fused into the state-sponsored institution. Thus, there was a central organization for laborers, peasants, fishermen, teachers, veterans, Islamic scholars, engineers, lawyers, journalists, medical doctors, youth groups, women, retirees, businesspersons, and artists. Moreover, Pancasila, massively socialized through official indoctrination by the state, was also obliged to be the sole foundation' for every one of these organizations. ${ }^{18}$ The Jakarta Charter, a 1945 historical document, which opened the door to the return of political Islam, was put off limits for any political discussion.

Understandably, Muslims reacted in different ways to Soeharto's regime that was authoritarian and immensely powerful. As far as Pancasila was concerned, most of the major Muslim organizations, such as NU and Muhammadiyah, were able to accept it without serious institutional problems as the sole foundation for each organization. Some others, however, such as Pelajar Islam Indonesi (PII, Indonesian Muslim Students), openly rejected it and chose to dissolve themselves and becomes 'underground' movements. Another group, Himpunan Mahasiswa Islam (HMI, Muslim Students' Association), experienced protracted internal conflict and finally split into two groups: one accepting, the other rejecting the "sole foundation" idea. Nevertheless, under the Soeharto regime, most Muslim groups eventually chose to concentrate on ritual and social programs or education without

17 James C. Scott, Seeing Like a State, How Certain Scheme to Improve Human Condition have Failed (New Haven and London: Yale University Press, 1998), p. 89.

18 In 1978, People National Assembly (MPR) issue a decree about this official national indoctrination of Pancasila called P4. An official institution, called BP7, was established to handle the huge job of indoctrination. 
entering the political arena. ${ }^{19}$ In fact, as noticed by Olaf Schumann, during that time, religious activities would be supported by the government only when it was advantageous to national economic development. ${ }^{20}$

\section{The Seeds of Liberal and Militant Islam}

Nevertheless, for Madjid, who later became the most important and outspoken 'locomotive' of the Indonesian Islamic thought reform movement, Soeharto's political behavior towards Muslims was "a blessing in disguise". Indeed, for him, since the 1945 independence, Indonesian Muslims had spent too much time and energy on politics. Nothing more than a deep political segregation that had brought Muslims nothing but powerlessness under Soeharto's authoritarianism, political Islam, in fact, did not suit the plurality of Indonesia. In response to this, there was a call for Muslims to understand and to apply Islamic values more substantially in social life beyond politics, beyond short term interests and conflicts under Islamic banners. Hence, from the 1970s Madjid promoted what was known as "Islam yes, Islamic political party no". In an era in which many people were so haunted by the danger of secularization as a consequence of modernization, he publicly declared that secularization was necessary, but it should be understood in order to wisely treat anything secular as secular, including politics, and anything profane as profane. Clearly, Madjid did not adopt the ideology of secularism. He also consistently argued that Indonesian Muslims should have no problem with Pancasila as the best common platform, creatively formulated by their founding fathers to meet the needs of Indonesia's multicultural and multi-religious society.

To encourage Muslims to participate in national development, Madjid also massively promoted the idea that Islam was definitely compatible with science, progress and modernity. For him, Islam and modernity were not incompatible or counter to each other. When modernization was understood as thinking and acting in accordance with natural law, then it was a historical necessity; it was a divine

\footnotetext{
19 Nurcholis Madjid, Islam Kemoderenan dan Keindonesiaan (Bandung: Mizan, 1998).

20 Olaf Schumann, "Christian-Muslim Encounter in Indonesia," in Yvonne Yasbeck Haddad, Christian-Muslim Encounters (Jacksonville: University Press of Florida, 1995), p. 291.
} 
order". ${ }^{21}$ Furthermore, Islam in itself is always inherently a 'modern' religion. In order to provide Muslims with theological foundation for their social interaction in a plural society, Madjid who was well trained both in pesantren (the traditional Islamic schooling system) and the Western system of education then formulated a widely praised (and criticized) idea of "Islamic inclusive theology". For many people, Madjid had indeed produced a strong and coherent intellectual response to Muslims' peripheral socio-political situation by means of establishing ethical and moral foundations for the national development project. ${ }^{22}$ Together with the Paramadina Foundation, which he founded in 1986 and which would later become a popular center for Islamic studies especially among urban Muslim middle class, Madijd laid a very important foundation for the development of liberal Islam in Indonesia.

From the same mold as Madjid is Abdurrahman Wahid, a three time-elected chairman of NU (1984-1999) and the fourth President of Indonesia. If Madjid's audience was mainly urban Muslim middle class, Wahid, who came from a very strong pesantren background, spoke mainly on behalf of and worked with traditionalist Muslims. Being aware of his people's potential and handicaps before the national development project, he articulated incessantly and critically the challenges and problems of modernization that had to be overcome by Muslims and the government together. While some Muslims promoted the purification of Islam, which often implied an anti-traditional culture stance, if not outright Arabization, he promoted the idea of "indigenization of Islam". For him, the adoption of local culture in a proper way was necessary if Islam needed to be an integral part of Muslims' life.

Many people at this time, including bureaucrats, held a negative view of Muslim traditionalists, that they were backward, ignorant, static minded, parochialistic and both economically and administratively poor. In response to this view, Wahid always reminded the government that modernization should be implemented in accordance with the needs, values and culture of the society - in other words, a bottom up, rather than top down policy of social engineering. In the

\footnotetext{
${ }^{21}$ Madjid, Islam Kemoderenan, p. 173.

22 Samsurizal Panggabean, "Enerji Utopia Nurcholish Madjid," Ulumul Qur'an, No. 1, Vol. IV (1993), p. 34.
} 
early 1970s, being aware of huge and long-term social costs resulting from the New Order's paradigm of modernization, together with many Muslim leaders and activists, Wahid founded Perhimpunan Pengembangan Pesantren dan Masyarakat (P3M, The Association for Pesantren and Community Development), an NGO that offered alternative social projects of empowerment especially for pesantren people.

Moreover, in response to political Islam, Wahid argued that instead of being taken as the only one, in the Indonesian context, Islam should be considered as one among the major resources for the establishment of the nation. Instead of being a counter disintegrative factor in the national life, Islam should be directed to be a complementary factor. ${ }^{23}$ While many political Muslims group cried out for their rights as the majority group, Wahid openly criticized any sectarian tendency among Muslims, actively involved himself in inter-religious programs, and tirelessly spoke up for the rights of minorities on behalf of democracy. Not only did he annul the widespread assumption about the incompatibility of the traditional Muslim world with modernity, Wahid's Islam, by definition, as Barton records, was dynamic, cosmopolitan, fundamentally tolerant and egalitarian. ${ }^{24}$

Together with people like Ahmad Wahib, Harun Nasution, Munawir Sjadzali, Djohan Effendi, and Dawam Rahardjo, Madjid and Wahid were among the first generation of modern Indonesian Muslim thinkers who nourished the seeds of Islamic liberalism during the first half of the Soeharto era in the 1970s. As was seen in the previous discussion, Islamic liberalism here emerged as Muslims' struggles with modernity. Challenges and responses from both sides departed from down-to-earth issues and situations. As reflected in Madjid's and Wahid's ideas, in responding to modernity, exponents of liberal Islam came out with genuine interpretations of universal values of Islam that were deeply rooted in its tradition and which were at the same time compatible with principles of modernity. It is also worth noting here that while this non-political Islamic thought reform was favorable to Soeharto's policy on Islam, it had nothing to do with political support

\footnotetext{
23 Abdurrahman Wahid, "Massa Islam dalam Kehidupan Bernegara dan Berbangsa," Prisma, Extra Edition (1984), pp. 3-9.

24 Greg Barton, "Pengantar," in Abdurrahman Wahid, Prisma Pemikiran Gus Dur (Yogyakarta: LKiS, 2000), p. xxx.
} 
for him, or at least it did not imply such support. As would be seen in later developments among Indonesian Muslims, when Soeharto was weakening in power, the seeds of liberal Islam began to grow as a significant contribution toward the establishment of civil society in the country.

Meanwhile, also as a reaction to the modernization projects launched by Soeharto's government, the seeds of Islamic militancy were growing. Unlike Islamic liberalism that had clearer intellectual foundations, however, Islamic militancy was rooted more in political activism. For those Muslim groups that inherited or at least were inspired by political Islam from the past, both nationally and internationally, the policies of Soeharto were perceived as a very serious threat both theologically and politically. Theologically, any separation of ritual Islam and political Islam, for them, would only make the religion lose its essence as 'a total system of life'. Politically, for them, Muslims who had already been weakened and kept so by the kuffa $\gg$ (infidels) for hundreds of years were now successfully marginalized even when they were the majority group.

For militant Muslims, the existing political situation of Indonesian Muslims at that time could be taken as evidence. Although Muslims were the majority group, they only played a minor role in national life. The economy, politics, bureaucracy and most of strategic positions were in the hands of non-Muslims. ${ }^{25}$ It is well known that during the first half of Soeharto's era Indonesian Muslims suffered from "numeric majority but mental minority syndrome". What made everything worse was the fact that the Center for Strategies and International Studies (CSIS), established in Jakarta in 1971 and organized mainly by Chinese and Catholic figures, was 'unofficially' appointed by Soeharto as his think-tank to handle the economic policies for the national development project. It is widely known that many influential figures behind Soeharto such as Ali Murtopo, Soedjono Hoemardani, L.B. Moerdani and others were CSIS people.

Meanwhile, another serious problem, in the eyes of militant Muslims, was that the so-called "trickle-down effect" approach of development had only invited massive and rapid Westernization and

\footnotetext{
25 This fact is understandable because, sociologically and historically, the well-educated group during the colonial period and several decades after independence were mainly Christians, while trading networks had long been in the hands of the Chinese ethnic group. Up until the 1990 s Soeharto was closer to these groups than to Muslims.
} 
secularization to Indonesia as a Muslim country. Further, for them, the increase in unemployment and crime rate, the huge corruption in the bureaucracy, the crisis of values among the youth, liberal ideas and behaviors, and various social dislocation problems were actually viewed as an intentional, long-term conspiracy by the enemies of Islam to destroy Islam and the Muslims. ${ }^{26}$

Finally, as a result, some small militant Muslim groups were involved in open confrontation with Soeharto's regime: Komando Jihad (1977), Jama'ah Imran Movement (1981), 27 Tanjung Priok riot (1984), and GPK Warsidi Lampung (1989). Some of these groups had certain connections with similar movements in other Muslim countries such as al-Ikhwa al-Muslimu (IM, the Muslim Brotherhood) founded in 1928 by Hasan al-Banna in Egypt, and Hizbut Tahrir (HT) founded in 1958 by Taqiyuddin An-Nabhani in Jerusalem, but some did not. With or without international connections, however, generally speaking, they shared the same commonalities. For example, these commonalities included the perceiving of Islam as the only ultimate total system of life and the call for establishing an Islamic state or, at least, Islamic shari $\gg$ h.

Nevertheless, Soeharto's powerful regime was beyond all their power capacity. Accused of organizing any effort to establish Islamic state and rejecting the idea of Pancasila as the sole foundation, they were effectively suppressed by the government. Soeharto even used these cases of militant Muslims to show his unchallenged power. Many people were killed in engineered riots', sent to jails or escaped to other countries. Apparently, Soeharto had an effective strategy to repress those Muslim militant groups and cut off their networking. However, while the old roots were paralyzed, the new Muslim militant groups emerged.

26 During this period, rumors about systematic, long-term Christianization of Indonesia, supported by Western countries such as U.S., Canada, and U.K. were widely spread. See, for example, Lukman Hakiem, Fakta \& Data Usaha-usaha Kristenisasi di Indonesia (Jakarta: Media Dakwah Magazine, 1991), pp. 53-59.

${ }^{27}$ Many sources convincingly show that these two groups were actually created by, or at least infiltrated by and then made used of by, Soeharto's military regime. Here CSIS is supposed to have played a very significant role. See, for example, Al-Chaidar, Bencana Kaum Muslimin di Indonesia (1980-2000) (Yogyakarta: Wihdah Press, 2000). 


\section{Education: Redemption of the Past, Conflict over the Future}

To understand better the development of both liberal and militant Islam in the modern history of Indonesia, it is interesting to examine what was happening in public education. Supposedly, in order to combat communism, the New Order regime created a policy obliging every individual to adopt one of the five official, acknowledged religions; Islam, Catholicism, Protestantism, Hinduism, or Buddhism. ${ }^{28}$ When, thanks to the "oil boom", in the early 1970s the government made substantial improvements in public education, among the others, by launching a compulsory education program and building thousands of elementary schools, called "SD Inpres", in every sub-district area throughout the country, ${ }^{29}$ the policy on obligatory adoption of religion was further implemented in schools. Religion became a compulsory subject from elementary to high school, even up to university level.

Two important things are worth noting here in relation to our topic of discussion. First, due to the compulsory course on religionespecially Islam in this case-, students coming from a "nominal Muslim" background, or "abangan', 30 were systematically made more and more familiar with Islam. Previously, the number of nominal Muslims, before and during the 1970s, was much larger than their fellow practicing Muslims, or santri, but after that period the numbers tended to be reversed. At the same time, unintentionally these students coming from nominal a Muslim background were 'detached' from their parents' traditional system of beliefs which were much closer to Hinduism or other local religions. Due to the limitations of learning time and the available teachers, the abangan students' understanding of Islam was somewhat limited in comparison to their fellow santri

\footnotetext{
${ }^{28}$ Confucianism, in fact, existed and was acknowledged as a religion during Soekarno's era, but, strangely enough, although the Chinese enjoyed various privileges under Soeharto, it was not admitted as a religion during the New Order regime. Together with various local religions, it faced problems of survival during that time.

29 This initiative was based on a special Inpres (Instruksi Presiden or Presidential Directives). Therefore the schools were called "SD Inpres".

30 About the discussion of the word abangan and santri that will be frequently used henceforth, read Clifford Geertz, The Religion of Java (New York: The Free Press, 1964). Of course, the abangan group in its strictest sense is a Javanese phenomenon. While keeping other non-Javanese ethnicity in mind, I will argue that what happened to Javanese as the largest and the most influential ethnic group in politics and culture would have a very substantial, or even 'exemplary', effect on the rest.
} 
students, who enjoyed regular, systematic and intensive learning on Islam both from daily life practices of their family and from the mosques or pesantren. Psychologically, on the side of abangan students, this fact left a sense of being less Muslim. Nevertheless, in the long term, this overturn among the abangan children certainly became a factor in the process of "santrinization" (Islamization) and the Islamic resurgence in Indonesia.

Second, since the majority of the population were Muslims, particularly the "practicing" Muslim (santri) benefited from this compulsory education program. For the first time, Muslims could enter a modern secular education system in a massive and affordable way. Before that period, practicing Muslim families would send their children mostly to pesantren ${ }^{31}$ to get a better education. Now, chances for vertical mobilization, such as those created by the need for a huge number of teachers-especially positions for courses on Islam as a compulsory subject-both to fulfill the large opportunities provided by the increase of schools numbers and to replace the fired communist teachers, become a significant and promising avenue for many practicing Muslim families to enter secular system of education.

As a result, according to William R. Liddle, ${ }^{32}$ over the following period, the number of educated "practicing" Muslims increased substantially. In this relation, as an initial consequence of national development in public education, according to Madjid, ${ }^{33}$ in the late 1970s, for the first time Indonesia had a significant number of university graduates, most of whom had "practicing" Muslim backgrounds. By the 1990s some of those graduates had come to occupy various significant positions in bureaucracy, while the others had become established professionals. At the same time, universities were now flooded with Muslim students, both from nominal and

31 Pesantren are mainly Islamic traditional boarding schools where students learn only Islam. Most of them are not acknowledged by the government in terms of a modern education system. About the differences, relations, tensions and development of Islamic traditional and modern systems of education in Indonesia, read Karel Steenbrink, Pesantren, Madrasah, Sekolah (Jakarta: LP3ES, 1986).

32 William R. Liddle, "Skripturalisme Media Dakwah: Suatu Bentuk Pemikiran dan Aksi Politik Islam Masa Orde Baru,” Ulumul Qur'an, No. 3, Vol. IV (1993), p. 61.

33 See Madjid, Islam Kemoderenan, p.81. 
practicing Muslim backgrounds of the "SD Inpres" generation. ${ }^{34}$ In short, thank to education, a new force of Muslim middle class was being formed..

In line with this massive educational improvement, one thing is worth pondering. The way Soeharto's New Order defined the past as a long story of collective memory of trauma: the bloody military coup of 1965, Soekarno's corrupt regime, the brutal occupation by the Japanese in 1942-1945, the inhuman Dutch colonialism for hundreds of years and so on; and they way it defined the future: i.e. modernity is the only rational choice for a definite brighter future, had a significant impact on this SD Inpres generation's perception in general. This applied to their perception of history and to other matters. As products of an education system shaped by the New Order, they also suffered from some kind of traumatic view of the past and a superlative dream of the future. This was then manifested differently depending on whether someone came from a santri or abangan background.

For those who came from a santri background, modernization, via their modern schooling system, had always tended to stigmatize them, implying that being santri was backward, static, poor, uneducated, unorganized, sectarian, narrow minded. In short, they learned that being santri was manifestly ugly in the face of modernity. Therefore, this should be overcome in one way or another. In the meantime, those who came from an abangan background learned from their schools that being abangan meant being irreligious, ignorant, faithless, a transgressor, superstitious, and polytheist. In short being abangan meant being sinful. As we shall see, these two perceptions of the past among young Muslims of SD Inpres Generation from different backgrounds eventually lead to conflict over the future.

Before that, however, now, let us go back first to Soeharto's politics. By the 1990s, a fundamental change had taken place in the Indonesian political constellation due to the shift of various elements of the society as a result of the national development project and influences from external factors. Against expectations, the New Order had lost much of its political power and stability. Soeharto's "growth

\footnotetext{
34 It is interesting to note that, perhaps due to long socio-historical and cultural backgrounds, when university level is affordable, many practicing Muslim families send their children to IAIN (State Islamic Universities under the Department of Religious Affairs that have close relations to the pesantren tradition), while those of a nominal Muslim background will send their children to secular universities.
} 
oriented" developmentalism, as the pillar of the order, was decaying for many reasons. Instead of real social economic betterment for all, economic gaps between the elite and the rest of the people grew wider and became irreversible. Despite its stable appearance, the regime's economic structure, as proven later, was actually very fragile. At the same time, huge diverse businesses run by each of Soeharto's children and growing mainly based on favoritism now became very a serious handicap for the health of the Indonesian national economic system. Corruption, collusion and nepotism, resulting from a long history of ill-managed bureaucracy, constituted a significant part of the national governmental system and led to a high cost economy, feudal "Yes, Sir" culture and political totalitarianism. Above all, international debt to the capitalist countries quadrupled.

Therefore, as he began to lose support from the military, ${ }^{35}$ President Soeharto, a pragmatist politician, then tried to win over the new emerging political force of the Muslim groups. ${ }^{36}$ In accordance with this, the long efforts made by such Muslim thinkers such as Madjid and Wahid, as have been discussed in a previous part of this paper, also made Soeharto feel more secure with Islam, or at least not as cautious as before.

Soeharto's government began more actively to sponsor many Islamic projects, especially non-political ones. Thousands of "Pancasila" mosques, funded by Yayasan Amal Bakti Muslim Pancasila (YABMP), one of Soeharto's foundations, were built all over Indonesia. Soeharto also launched a "1000 da'i (Muslim preacher) Movement" by sending a thousand Muslim preachers to transmigration areas. ${ }^{37}$ Various festivals on Islam, such as Istiqlal

\footnotetext{
35 Due to the betterment of education among the Muslims, rivalry between Christians and Muslims within the Indoneisan military wase evident at that time. On February 28, 1988, LB Moerdani, a smart and visionary Catholic general with huge influence within the Indonesian military was abruptly remoeved by Try Sutrisno, a young emerging Muslim military star and Soeharto's close adjutant. Read Ben Anderson, "Current Data on the Indonesian Military Elite," Indonesia, Vol. 48 (October 1989), pp. 65-96.

36 Liddle, "Skripturalisme Media Dakwah".

37 This movement aimed at two directions: 1) to improve a designed religious life among the Muslim transmigrants in their new settlements outside Java and 2) to persuade more people (including those with more knowledge about Islam) to participate in transmigration programs, as a means of handling the population problem and the huge disparity between Java and outside it. Obviously, this was part of Soeharto's social engineering.
} 
Festival and National Qur'aæRecital Competition, were also celebrated annually or periodically. In effect, Islam in general enjoyed more freedom to grow. Parliament became greener, symbolizing Muslim domination. In accordance with all of the above, ICMI (Ikatan Cendekiawan Muslim se-Indonesia, all-Indonesian Muslim Intellectual Association), a real articulation of the Islamic resurgence among the educated Muslim middle class, was founded in 1990. With full support from the President, Habibie, one of Soeharto's closest ministers, who later became the third Indonesian president, was appointed chairman of this association. Soeharto himself became its distinguished advisor. ${ }^{38}$

A spirit of Islamic resurgence was observable everywhere. More than in other places in the country, this Islamic resurgence was especially transparent in certain universities and among the more welleducated groups. Interestingly, a zeal for being correctly Islamic, being true Muslims and possessing the spirit to practice Islam totally in every aspect of life appeared much stronger among the Muslim students of secular-state universities. During the fasting month of Ramadła, many corners of secular campuses would be crowded with students busy with discussions, studies, seminars, workshops, and various festivals on Islam. In fact, by that time, as a result of extensive translation, books, ideas, and even the movement methods and organizational structures of militant Muslim thinkers like al-Banna and al-Mawdudi were very popular in Muslim student circles in most reputable "secular-state" universities such as UI (Universitas Indonesia), UGM (Universitas Gadjah Mada), ITB (Institut Teknologi Bandung), IPB (Institut Pertanian Bogor), UNPAD (Universitas Padjajaran), UNAIR (Universitas Airlangga) and others. The word "Islamic" was used extensively to demonstrate the embodiment of the spirit of "being a total Muslim" or practicing Islam correctly and totally. From this time on, so-called Islamic journalism, Islamic fashion, Islamic press, Islamic food, Islamic sport, and Islamic music became parts of the new national discourse. Certain typical 'Islamic' ways of dressing, addressing peer groups, behaving, and the use of particular vocabularies were intentionally used as a means of self-identification.

As indicated in the previous section, when carefully investigated, most of these groups' members, so energized by the Islamic resurgence, in fact came from the "SD Inpres generation" of "nominal

38 On the dynamics of this period, read for example, Hefner, Civil Islam. 
Muslim" families who, psychologically speaking, were suffering from a kind of "less Muslim" syndrome. Why was this so? Uprooted from their parent's tradition, on the one hand, and with minimal knowledge about Islam from formal educational institutions on the other hand, this "SD Inpres" generation from nominal Muslim families now, in the era of the Islamic resurgence, became "eager Muslims". Furthermore, their eagerness in being "true Muslims" grew in a situation where the social and political reality was shaped by the New Order in such a way as described in the previous part of this article. In this sense, I will argue that, more than just eager to true Muslims, these young people actually became an "anxious generation".

They were anxious about their past: their childhood, their parents' way of life, the neighborhood where they grew up, all of which could be seen as far from the "true guidance" of Islam. Some of them would refer to their past as a zaman jabiliyah (period of ignorance). They were anxious about the present, i.e. their social life that suffered from so many complicated problems: "moral decadence", economic inequality, massive corruption, and political authoritarianism. Meanwhile, the Muslim people, supposedly ordered to "enjoin what is right and forbid what is wrong", 39 were so powerless and even tended to ignore their reality. Islam as they saw it around them was merely a set of empty rituals. They were also anxious about the future: in a very highly competitive and limited job market, what would be left for them? Who would marry them? Where was their place in this uncertain period of rapid social change? A luxury predicate attached to university students as "the future leaders" frequently just added to their accumulative burden of anxiety. Yes, theoretically, with higher education they were expected to have more access to vertical mobilization. However, in practice, higher education now frequently meant disguised unemployment.

In short, they were a generation dreaming of immediate solutions to a very complicated situation. At this point, Islam, formulated in such a modern and 'certain' way as a means of analysis and as a solution to real problems, as promoted by al-Banna and al-Mawdudi, met their needs appropriately.

39 Taken from al-Qur'an, chapter III: 110 which is frequently used to describe the true nature of Muslims. 
With secular campuses as centers and students as the main proponents, in Jakarta, Bandung, Yogyakarta, Surabaya, Medan, Ujung Pandang and Indonesia biggest cities, Islamic resurgence spread rapidly to other elements of society. At UGM Yogyakarta, Jama'ah Shalahuddin, an intra-curricular organization for Muslim students became an important center of Islamic da wab both inside and outside the campus. Around Jama'ah Shalabuddin many smaller groups of students intensively and systematically studied and practiced Islam 'as correctly as possible'. Usually these small groups consisted of five to seven people under a mentor. The mentor himself or herself belonged to another peer group at a higher level with almost the same number of people. Books by al-Banna, Abul A`la al-Mawdudi, Sayyid Qut\}, Sayyid Sałiq, Sai $\gg 1$ Hawwa, and Fathi Yakan were used as sources for their studies. This was also the case with Masjid Salman for ITB in Bandung and similar organizations on other secular campuses.

A parallel development also took place on Senior High School campuses throughout the country. Islamic section, a sub-organization under OSIS, the only intra-organization for High School students allowed by the government, became a center for learning intensively about Islam. ${ }^{40}$ During 'summer vacation' many alumni from each High School, now attending universities, would go back to their alma maters to share their spirit and experiences of being part of the 'true young Muslim generation' in a short course program known as 'Pesantren Kilat'. Since the 1990s most urban mosques' activities and programs came to be dominated by these young eager Muslims.

In general, this Islamic resurgence was not an organized movement. Despite some informal coordination relating to current issues, information sharing, and certain temporary joint programs etc, so far there was no structural organization among the movements within universities and high school campuses or outside them at national level. However, so many people shared the same dream: how to transform Islam in their life into a solution for problems.

In their later development, I would argue, these young Muslims, so energized by the Islamic resurgence, could be classified into three main groups: the sympathizers, the activists, and the militants. The first

\footnotetext{
40 In early 1991 the Department of Education finally agreed to let women Muslim students who wanted to wear jilbab (veil) to do so as a response to the increase of protests against the previous prohibition for the reasons of school uniform.
} 
group, the sympathizers, were people involved mainly on the surface level of the movement. Their involvement might be only for few years during their study time or when they had immediate connection to it. Once they found a 'normal' or even established place in society after finishing school and got reasonable job, these people usually would return to a 'normal life'. The dream of Islamic resurgence and the motivation to translate Islam totally into social life would fade somewhat from their mind.

The second group consisted of those who were intensively involved in the Islamic resurgence movement during and after their studies. These young people usually maintained contact with their activist friends, creating sustainable programs and expanding networks into wider society as part of a serious, long-term effort to realize an exemplary Islamic society. Thanks to their persistent efforts there emerged Islamic banks, an Islamic press, Islamic businesses, Islamic culture and other Islamic networks. As soon as Soeharto fell from power in 1998, these young activists established the Islamic (Welfare) Justice Party (PKS) with great success in the following two general elections, especially among the well-educated young people in urban area. ${ }^{41}$ Instead of an Islamic State, their main objective was the creation of an Islamic society. So far they have become well known for their excellent performance in "high politics".

The last group, the militants, refers to vehement young people who were eager, not only to create Islamic society, but also to formally implement Islamic Law (shari ${ }_{\mathrm{a}}$ ), with or without the establishment of an Islamic State in Indonesia. ${ }^{42}$ For them, only when Muslims

\footnotetext{
${ }^{41}$ From its inception, especially thanks to its promotion of high moral standards, social humility and concrete programs for the people, the PKS rapidly gained sympathy and influence in Indonesian politics. In only a brief period, the PKS - being the sixth biggest party with more than 8 million votes in the 2004 election-could see one of its leaders, Hidayat Nur Wahid (44) as the chairman of the People Consultative Assembly or MPR, the Indonesian Senate. Visit their website here: www.pk-sejahtera.org

42 However, it does not mean that the young "nominal Muslim" or abangan is identical with militancy. What I mean here is that today we find a tendency towards militancy among young people from a nominal Muslim background. In this regard, it is also important to divide pesantren into two categories: namely 'cultural' pesantren and 'political' pesantren. The latter are political in the sense of adopting the idea of an Islamic state as a necessary condition for an Islamic society, an idea that is absent among the former. In relation to Islamic militancy, the second type of pesantren plays an important role in providing it with leadership.
} 
implemented Islamic Law based on the Qur'aæ and Sunnah, would those complicated problems disappear. Otherwise, Muslims would never escape their current miserable life and would continue to lose out. Unlike the second group, who had no immediate structural or organizational connection with international movements, most of the militant Muslim groups had global connection with similar movements in other countries.

Some of those connections were HT, Jama'ah Tabligh, Darul Arqam, IM, and various Salafist groups that were originally established in Palestine, India, Malaysia, Egypt and various Middle Eastern countries. Each of those groups had chapters with significant followers in many larger cities in Indonesia. Forum Komunikasi Ahlussunnah wal Jama'ah (FKAWJ) founded in 1998, Laskar Jihad, founded in 2000, Majelis Mujahiddin Indonesia (MMI) founded in 2000, Pesantren Ngruki in Surakarta, Central Java, and FPI (Front Pembela Islam, Islam Defenders Front) founded in 1998 in Jakarta, were other strong militant groups with less identifiable international connections. ${ }^{43}$

In addition to introducing the promise of immediate exact solutions to every problem in Indonesia, those groups also involved Indonesia in issues borne by Muslims in other parts of the world. For example, direct encounters with veterans of the Afghanistan war and the Moro Muslims movement in Philippines among some of their groups' members, provided evidence of the concreteness of the threat to Muslims and thus the urgency of their involvement. Like mushrooms in the rainy season in a tropical fertile land, these militant groups grew rapidly after the New Order regime collapsed in 1998. Big cities like Jakarta, Bandung, Yogyakarta, Solo, Surabaya, Medan, Palembang and Muslim-Christian conflict areas in Eastern Indonesia become the main enclaves of these movements. Their numerous publications, like books, leaflets, and weekly bulletins published by Wihdah Press and Al-Izzah Press as well as Suara Hidayatullah Magazine, ${ }^{44}$ Sabili Magazine, ${ }^{45}$ As-Salafi Magazine ${ }^{46}$ and Al-Islam and $A l-W$ 'ie Journals, just to mention a few, very clearly proclaimed their

\footnotetext{
43 Giora Eliraz, Islam in Indonesia, Modernism, Radicalism and the Middle East Dimension (Brighton, Portland: Sussex Academic Press, 2004).

${ }^{44}$ http://www.hidayatullah.com/

45 http://www.sabili.co.id/

${ }^{46}$ http://salafy.cjb.net/
} 
militant campaign. Many of these aforementioned groups, especially those with links to the Middle East, could be categorized, as Hefner calls them, as "neo-fundamentalist or neo-salafist" with strong beliefs that Israel and the US are leading an international conspiracy to destroy Islam and therefore armed jihad is a necessary response from Muslims. ${ }^{47}$ For them, the enemy is clear, present, and offensive.

To paint a clearer picture of Islamic militancy in Indonesia, I will now provide a brief illustration of MMI, ${ }^{48}$ one of the strongest militant Muslim groups. This organization was established in Yogyakarta, the Indonesian center of education par excellence. Through the first and second Mujahidin Congresses held in Yogyakarta and Solo and attended by thousands of participants, Abu Bakar Ba'asyir (67) was elected twice (2000-2003 and 2003-2008) as its leader. ${ }^{49}$ There is no accurate data on its membership today. Nevertheless, from its numerous branches in Java, Bali, Sumatra and other parts of Eastern Indonesia and the number of its delegates at the last two congresses, it can be inferred that its members could run to tens or even hundreds of thousands. Most of them are young and well-educated people. Irfan S Awwas, second to Ba'asyir, is a graduate from UGM.

The main goal of MMI is the enforcement of Islamic Law in Indonesia. The "Jakarta Charter", not surprisingly, is used by MMI as one of the main entry points to achieve their legal target. MMI is also very seriously and systematically presenting to the public the concept

${ }^{47}$ Robert W Hefner, Civil Pluralism Denied? The New Media and Jihadi Violence in Indonesia, Unpublished paper (2002), p. 6.

48 http:/ /www.majelis.mujahidin.or.id

49 Ba'asyir himself, a graduate from al-Irsyad University in 1963, is the central figure of pesantren Ngruki, Solo, Central Java, which he established in 1972. (Ngruki is an example of what I call a 'political' pesantren.) He was jailed for 9 years in 1983 due to his opposition to Pancasila as the sole foundation, and then escaped to Malaysia in 1985 while his case was still in process. From then on he was actively involved in da wah, both in Malaysia and Singapore. He returned to Indonesia in 1999 and organized MMI. He was arrested, charged with being head of Jama'ah Islamiah (JI), an alleged affiliation or partner group of al-Qaeda in Southeast Asia, and for his role as the intellectual actor behind the Bali bombing and other bombings in Indonesia. For his short biography, see http://www.tempointeraktif.com/hg/narasi/2004/04/17/nrs,20040417-02,id.html. Interestingly, Frederick Burk, a former official translator for US President, from Clinton to Bush, declares that the accusation of Ba'asyir in his involvement in JI is just an "American scenario" for the American government in particular, or for Western interests in general. About this, sees Riza Sihbudi, in http:/ / www.republika.co.id/kolom_detail.asp?id=184149\&kat_id=16 
of Islamic shari $x_{h}$. Trainings on holdu (Islamic criminal law), including the law on adultery, apostasy, theft, drugs and even terrorism, are held regularly. Moving even further, MMI has already presented a draft of an amendment to alter the Indonesian constitution in order to make it fit Islamic Law. MMI members use almost every social, political, economic and cultural problem as example of the consequences of the implementation of secular kufr law and thus the immediate necessity for the application of Islamic Law as the final solution. Such themes as "Wanted: a President committed to Islamic Law" and "Being a Total Muslim: Plunging ourselves into Total Islamic Law" as well as "The Western Strategy to Destroy Islam" and the like are their main daily topics of discussion. Although so far none of their activities has been physically violent, obviously many items on their agenda are antidemocratic and anti-pluralist-such as the stipulation that a nonMuslim could not become president of Indonesia - and thus have resulted in various degrees of unease among non-Muslims.

In the meantime, immediately before and soon after Soeharto was toppled in May 1998, various racial and inter-religious conflicts erupted in different places throughout the country such as the Tasikmalaya and Situbondo riots (1996), Pekalongan riot (1997), Ketapang riot (1998) and others. ${ }^{50}$ In Ambon, in eastern Indonesia, a vicious MuslimChristian conflict broke out in January 1999 and lasted more than a year. Assuming that government could not be trusted to handle these problems, Laskar Jihad, based in Yogyakarta and one of the most vehement militant groups sent thousands of its members to the conflict area. ${ }^{51}$ Understandably, the strong emergence of militant Muslims in the aforementioned conditions eventually resulted in deep concerns not only among non-Muslims, but also among Muslims themselves. As I mentioned earlier, claiming that many modern principles such as pluralism, tolerance, democracy, religious liberty, religion-state separation and others, are definitely compatible with Islamic teaching, Islamic liberalism had been developing since the

\footnotetext{
${ }^{50}$ Read Mohtar Mas'oed et. al., Kekerasan Kolektif, Kondisi dan Pemicu (Yogyakarta: P3PK UGM, 2000).

${ }^{51}$ Discussion on Laskar Jihad, read, for example, Noorhaidi Hasan, "Faith and Politics: The Rise of Laskar Jihad in the Era of Transition in Indonesia," Indonesia, No. 73 (April 2002), pp. 165-169. Also read Sukidi Mulyadi, "Violence under the Banner of Religion: the Case of Laskar Jihad and Laskar Kristus," Studia Islamika, Vol. 10, No. 2 (2003), pp. 75-110.
} 
1970s in Indonesia. Obviously, since santri (referring to the people) and pesantren (referring either to the system of education, its physical building, neighborhood, culture or a certain section of society) were those who struggled with these Islamic-modernity compatibility issues, Islamic liberalism developed mostly among them, especially among young santris who had access to modern higher education. If Islamic militancy found a better place to grow in many secular state universities, IAIN52 (Institut Agama Islam Negeri, State Institute for Islamic Studies) and other private Islamic universities became the main development centers of Islamic liberalism. ${ }^{33}$ Together with IAIN, HMI and PMII, two major extra-campus Muslim students associations that used to be affiliated under Muhammadiyah and NU respectively, also played similar roles in sowing the seeds of Islamic liberalism.

Among others, it was this young well-educated santri group that had serious concerns about the stronger emergence of Islamic militancy. From among them, various studies, forums, movements, networks and organizations soon emerged, either directly as counterweights to Islamic militancy, or indirectly, in a wider sense, as initiatives to promote inclusive, tolerant and liberal Islam in relation to specific issues such as pluralism, human rights, democratization, civil society, gender equality etc. Just to provide some examples, LKiS (Lembaga Kajian Islam dan Sosial, Institute for Islam and Social Studies) was founded in Yogyakarta (1993), FSAS (Forum Studi Agama dan Sosial, Forum for Religious and Social Studies) was founded in Jepara (1997), Desantara was founded in Depok (1998), LAPAR (Lembaga Advokasi dan Pendidikan Anak Rakyat, Institute of the People's Children for Advocacy and Education) was founded in

52 IAIN is a state Islamic university with a secular model, built in almost every provincial capital city and even in smaller towns throughout Indonesia. Due to cultural, economic and other reasons, most of its students come from santri families or a pesantren background. For more about IAIN read, for example, Johan Hendrik Meuleman, "The Institut Agama Islam Negeri at the Crossroad," in Johan Hendrik Meuleman (ed.), Islam in the Era of Globalization, Muslim Attitude towards Modernity and Identity (London: RoutledgeCurzon, 2002), pp. 281-298.

53 Militant groups continually criticize IAIN over this concern. For example, read Hartono Ahmad Ja'iz, Ada Pemurtadan di IAIN (Jakarta: Pustaka Al-Kautsar, 2005). After presenting the whole list of IAIN's 'sins', the book concludes that there is a very dangerous, systematic conspiracy behind the project of liberalization of Islamic thought at IAIN, sponsored by the West in order to make Muslim youths finally renounce their faith. 
Makassar (1999), JIL (Jaringan Islam Liberal, Liberal Islam Network) was founded in Jakarta (2001), JIMM (Jaringan Intelektual Muda Muhammadiyah, Muhammadiyah Young Intellectual Network) was founded in Jakarta (2003) and many others.

In this discussion, JIL will be presented as an example of liberal Muslim group since it uses liberal Islam as its self-reference. ${ }^{54}$ Unlike MMI, which was founded after a huge public gathering (tabligh akbar) attended by thousands of Muslims, JIL was founded at a very small meeting attended by some seven people. From the very beginning, JIL's motive has been clear: "to counter the growing influence and activism of militant and radical Islam in Indonesia". According to Ulil Abshar-Abdalla, who became the coordinator of JIL, "We've seen radical Islam grow militant, systematic and organized, while liberal Islam has been unorganized, week-seeming, not militant, not resistant and unassertive in giving voice to its perspective. The Liberal Islamic Network was in fact motivated by the appearance of these radical Islamic movements." 55 Thanks to an effective network, established by its exponents, both in terms of financial support and mass media, JIL achieved public recognition immediately. ${ }^{56}$

As displayed on JIL's website, ijtiha (defined as 'rational thinking of Islamic texts), non-literal understanding of texts, pluralism, minority rights, religious liberty, the separation of religion and state, and democracy, are among JIL's key words. Not surprisingly considering its initial motives, JIL's main interest has been related to criticism of such things as intolerant attitudes among Muslims, religion as a source of violence, women's oppression, literalism and formalism etc. In connection to that, Abshar-Abdalla, the coordinator, and JIL's other main exponents, many of whom are very well trained both in pesantren

\footnotetext{
${ }^{54}$ For general discussion on JIL, read Muhammad Ali, "The Rise of the Liberal Islam Network (JIL) in Contemporary Indonesia," American Journal of Islamic Social Sciences, Vol. 22, No. 1 (Winter 2005), pp. 1-27.

55 Linda Christanty, "Is There a Rainbow in Islam," Latitude Magazine, July 30, 2003.

56 In terms of financial support, JIL is backed up significantly by The Asia Foundation and Freedom Institute, while in the mass media, it is supported mainly by Jawa Pos and $68 \mathrm{H}$ Radio Channel in Jakarta. JIL also has its own beautiful bilingual IndonesianEnglish website: http://www.islamlib.com.

${ }^{58}$ It should not be understood, however, that JIL's members are all santri or that santri in general is identical to liberal. What I want to say here is that there is a strong relation between Islamic liberalism and young santris who have enough modern education.
} 
and modern education systems, ${ }^{58}$ offer hermeneutic and theological breakthroughs in understanding Islam, particularly in relation to modern issues. In one of his most controversial articles, for example, Abshar-Abdalla argues that Islam is not a monument as assumed by many people. In understanding Islam, Muslims should really pay due attention to context and distinguish between the fundamental principles and their cultural manifestations. The jilbab (veil for women), hand-amputation, qis d 8 s stoning, beards, wearing robes, are merely examples of Arabic cultures, and thus there is no obligation to practice them. Inter-marriage prohibition is now irrelevant; religion is basically a private matter; there is no such thing as 'divine law'; Muhammad, the prophet, is a historical figure with some weaknesses and should be studied critically, [non-verbal] waby did not stop after Muhłmmad, but is still being revealed, including among Western people with their modern achievements; religion, including Islam is just like a tool 'for the total submission to the Absolute Truth' and people should not quarrel with each other for the sake of it and that the real message of Islam is justice. The real message of Islam therefore is not the jilbab, domestication of women, growing beards, or shortening men's pants. Human problems could never be solved by applying Islamic shari $x_{\mathrm{a}}$. To understand that Islamic shari $x_{\text {hh }}$ is a ready-made packet from God to solve every human problem is an indication of ignorance and incapability to perceive sunnatullab itself. The most dangerous enemy of Islam is, in fact, dogmatism, to refer to Islam and the West as 'us' and 'them' in the sense of 'the good and evil' consecutively, is a manifestation of a social pathology that eventually will destroy Islam itself. ${ }^{59}$

This article that was injudiciously published during Ramadł immediately kindled furious reactions from militant Muslims. A death edict was even issued by a group of Muslim militant `ulama $>$ in Bandung, West Java. Since its inception, JIL has stood in almost diametrical opposition to the militant groups. In many ways, apparently, each group has striven to eliminate the other. The most recent case erupted just a few months ago, when MUI (Majelis Ulama Indonesia, Indonesian Council of Islamic scholars) issued 11 fatwas on various matters it claimed had been brought to the attention of this state-sponsor `ulama $>$ council by the Indonesian Muslim public. One

${ }^{59}$ Kompas, November 18, 2002. 
of them was the prohibition of liberalism, secularism and pluralism in Islam. ${ }^{60}$ As a result, the long-heated debate between both camps exploded again. Moreover, physical agitation and petitions by the militant groups to the government to dissolve JIL are still in the air as I write this paper.

Particularly in the post-Bali-bombing and post 9/11 atmosphere, the ways JIL promotes liberal ideas and how it reconstructs or deconstructs Islam, are not unproblematic. For some people, if Muslim militants are assumed to suffer from religious paranoia, so do the liberals in JIL when they exaggerate the role of militants as the 'whole' problem of Islam today. Not only does this eventually lead JIL to apply what Hugh Goddard calls a 'double standard',61 comparing the ideal versus the real between modernism and Islam, which in turn makes them say too much 'yes to the West' while hyper-criticizing their fellow Muslims, but it is also unfair to Islam in general and unhelpful in improving Muslims' situation and condition in particular. ${ }^{62}$

It is easy to find a continuity of ideas between JIL and the previous Indonesian liberal Muslim thinkers such as Madjid and Wahid. ${ }^{63}$ However, neither the way they address the issues nor how they articulate them is similar. ${ }^{64}$ As well as JIL's initial motive as a countermovement, in my opinion, the sociological background of these young people has played a significant role here. Belonging to a generation from what was the 'loser' group, the santri, who could eventually escape their 'ugly' past thanks to modernization, now these young people are trying to redeem their past. In contrast to their past, thanks

${ }^{60}$ The Jakearta Post, July 30, 2005.

${ }^{61}$ Hugh Goddard, Christians and Muslims: From Double Standards to Mutual Understanding (Richmond: Curzon Press, 1995).

${ }^{62}$ Read, for example, A. Mustofa Bisri, "Menyegarkan Kembali Sikap Islam, Beberapa Kesalahan Ulil Abshar-Abdalla," Kompas, December 4, 2002.

${ }^{63}$ In fact, Madjid himself had great expectations of JIL as the next 'locomotive' of the Islamic thought reform movement in Indonesia. Read Budhi Munawar-Rachman, "Cak Nur dalam Ijtihad Paramadina," Gatra, No. 43 (September 5, 2005).

64 It is interesting to see some similarities between JIL and MWU (Muslim Wakeup.com) in relation to their 'superior attitude' towards other Muslims with different viewpoints that eventually resulted in uncomfortable relations with their coreligionists. About PMU in this matter, for example read Muqtadir Khan, Is Muslim Wakeup.com Undermining the Progressive Muslim Movement? Visit: http://www.ijtihad.org/Muslimwakeup.htm. 
to achievements in modern education, instead of backwardness, parochialism, static-mindedness, and the like, being santri has meant belonging to a privileged group with sufficient skills to explore the 'sacred territory' of religion-a privilege which does not belong to those of an abangan background. By idealizing modernity and slapping the face of dogmatic, narrow-minded, out of context and 'anti-rational' Muslims, they have enjoyed intellectual pleasure as modern people. Thus they have redeemed their dark history.

However, the same is the case with the militants on the opposite side. Belonging to a generation that could learn a great deal from the blessings in disguise of modernization, they have now become the real defenders of Islam. By idealizing Islamic history and at the same time vehemently fighting every supposed enemy of Islam, including Muslims who they assume to practice Islam incorrectly or only at their will, this group has enjoyed religious pleasure as the true Muslims. At the same time, they are also redeeming their 'sinful' past as abangan who were always accused of being irreligious, ignorant, and unfaithful. The challenge of Islamic liberalism only justifies their position as the group entrusted with defending the 'true' Islam.

In relation to the experience of modernization under the "high modernist" ideology applied by Soeharto, apparently both liberals and militants are products of a modern education that suffered from a kind of 'modernist arrogance', both towards the past and towards others who have a different world view. Shaped under Soeharto's national development project with its 'high modernist' ideology that saw itself as a rational solution for the future of man, 'being educated' for the liberal and 'being religious' for the militant, has meant being superior, and having a right to judge, or even to punish, the other.

It is also worth noting that, despite their relation with modernization project launched by Soeharto's government, in the final analysis, neither the militants nor the liberal Muslims featured in the New Order's scenario. As we saw, militant Muslims emerged as an 'unintended, subversive result' of the New Order's agenda. While deriving benefits from modernization project, such as the adoption of technology and organization, they continued to oppose modernization as the main cause of the Muslim World's degradation in general. More than anything else, the militants like MMI and Laskar Jihad believe that modernization, interrelated with Westernization, secularization and liberalism, is the epicenter of Muslim society's catastrophe. These 
phenomena constitute the enemy of most 'real' Muslims', an enemy that should be conquered. On the other hand, as an 'expected result' of modernization, liberal Muslims have, in fact, adopted some key principles of the modern world, such as democracy, pluralism, civil and religious liberties, separation of religion and state, gender equality, freedom of speech and others. However, thanks to these modern ideas, interwoven with Islamic values, they could empower the structure and culture of civil society among Muslims to finally, in many cases, stand in opposition with Soeharto's authoritarian state. In my opinion, therefore, the militants and the liberals are actually two unwanted twin children of the same mother by the name of modernization. Furthermore, due to their different backgrounds and perspectives on Islam, modernization has made them stand in opposition to each other and to compete over the 'right' place of Islam in the Indonesia of the future

\section{Conclusion}

As I have demonstrated, the interplay between Islam and modernity is always complex, with various degrees of hope, tension, struggle, unpredicted results, consequences, costs and paradoxes among Muslims. Based on the above discussion, let me now conclude this paper with several important points. First, the tension now manifest between liberal and militant Muslims in present day Indonesia is actually not a new phenomenon. It has deep roots in Indonesian Muslim history. Nevertheless, modernization has provided it with new and very different conditions, dimensions and orientations.

Second, although Islam was initially used as political tool by Soeharto and his New Order government, both to support and to secure power, eventually Islam has its own story. Thanks to the improvement of public education through the massive development of SD Inpres and obligatory courses on religion in the 1970s as part of New Order's effort in political mapping and social engineering, a significant shift in religious orientation among Muslims took place in the following decades. If, in the past, the santri group was among the most serious targets of modernization, due allegedly to their backwardness, parochialism, and static-mindedness, now they are the main exponents of Islamic liberalism. On the other hand, from an abangan background, a group that was assumed to be identical with unfaithfulness, polytheism, and ignorance of Islam, has now emerged 
strong Islamic militancy. However, both groups eventually become counter movements to the New Order's initial scenario of power.

Third, in perceiving and competing with each other, both Muslim militants and liberals actually are redefining themselves while redeeming their own 'dark' history as produced by New Order's modernization. The 'ugly' past for the santri group and the 'sinful' past for the abangan are redeemed by being liberal or militant. At the same time, by their antagonism, not only do they achieve a 'privileged' position, but also they enjoy a certain pleasure in accusing the other of being the 'enemy' of Islam. Apparently, the nature of the "high modernist" ideology under which both groups developed has significantly influenced their characters.

Fourth, the present day conflict between Muslim militants and liberals over the 'right' place of Islam in Indonesia in fact reflects the long struggle of Muslims in the country in their negotiation with Islam, modernity and their social reality.

\section{Bibliography}

\section{Books and Articles}

Ali, Muhammad. "The Rise of the Liberal Islam Network (JIL) in Contemporary Indonesia." American Journal of Islamic Social Sciences, Vol. 22, No. 1, winter 2005: pp. 1-27.

Anderson, Ben. "Current Data on the Indonesian Military Elite." Indonesia. Vol 48, October 1989: pp.65-96.

Barton, Greg. "Pengantar." in Abdurrahman Wahid. Prisma Pemikiran Gus Dur. Yogyakarta: LKiS, 2000.

Boland, B.J. The Struggle of Islam in Modern Indonesia. Leiden: The HagueMartinus Nijhoff, 1971.

Chaidar, Al-. Bencana Kaum Muslimin di Indonesia (1980-2000). Yogyakarta: Wihdah Press, 2000.

Eliraz, Giora. Islam in Indonesia, Modernism, Radicalism and the Middle East Dimension. Brighton, Portland: Sussex Academic Press, 2004.

Geertz, Clifford. The Religion of Java. New York: The Free Press, 1964.

Goddard, Hugh. Christians and Muslims: From Double Standards to Mutual Understanding. Richmond: Curzon Press, 1995. 
Hakiem, Lukman. Fakta \& Data Usaha-Usaha Kristenisasi di Indonesia. Jakarta: Media Dakwah Magazine, 1991.

Hasan, Noorhaidi. "Faith and Politics: The Rise of Laskar Jihad in the Era of Transition in Indonesia." Indonesia. No. 73, April 2002: pp. 165-169.

Hefner, Robert W. Civil Islam: Muslim and Democratization in Indonesia. Princeton and Oxford: Princeton University Press, 2000.

Hefner, Robert W. "Civil Pluralism Denied? The New Media and Jihadi Violence in Indonesia.” Unpublished paper, 2002.

Ja'iz, Hartono Ahmad. Ada Pemurtadan di IAIN. Jakarta: Pustaka AlKautsar, 2005.

Karim, M. Rusli. Islam dan Konflik Politik Era Orde Baru. Yogyakarta: MW Mandala, 1992.

Liddle, William R. "Skripturalisme Media Dakwah: Suatu Bentuk Pemikiran dan Aksi Politik Islam Masa Orde Baru." Ulumul Qur'an, No. 3, Vol. IV (1993).

Ma'arif, Ahmad Syafi'i. "Islam as the Basis of State: A Study of the Islamic Political Ideas as Reflected in the Constituent Assembly Debate in Indonesia." Unpublished Ph.D Dissertation. Ohio University, Athens, 1982.

Madjid, Nurcholis. Islam Kemoderenan dan Keindonesiaan. Bandung: Mizan, 1998.

Mas'oed Mohtar, et.al. Kekerasan Kolektif, Kondisi dan Pemicu. Yogyakarta: P3PK UGM, 2000.

Meuleman, Johan Hendrik. "The Institut Agama Islam Negeri at the Crossroad." in Johan Hendrik Meuleman (ed.). Islam in the Era of Globalization, Muslim Attitude towards Modernity and Identity. London: Routledge Curzon, 2002: pp. 281-298.

Mulyadi, Sukidi. "Violence under the Banner of Religion: the Case of Laskar Jihad and Laskar Kristus." Studia Islamika. Vol. 10, No. 2 (2003): pp. 75-110.

Noer, Deliar. Partai Islam di Pentas Nasional, Kisah dan Analisis Perekembangan Politik Indonesia, 1945-1965. Bandung: Mizan, 2000. 
Peacock, James L. Purifying the Faith: The Muhammadijah Movement in Indonesian Islam. Menlo Park, California: The Benjamin/Cummings Publsishing Company, 1978.

Ramage, Douglas E. Politics in Indonesia: Democracy, Islam and the Ideology of Tolerance. London and New York: Routledge, 1995.

Roff, William R. "Kaum Muda-Kaum Tua: Innovation and Reaction Amongst the Malay, 1900-1941." in K.G. Tregonning (ed.). Paper on Malayan History. Singapore: Journal South East Asian History, 1962: pp. 162-192.

Samsurizal, Panggabean. "Enerji Utopia Nurcholish Madjid." Ulumul Qur'an. Number 1, Volume IV, 1993.

Schumann, Olaf. "Christian-Muslim Encounter in Indonesia," in Yvonne Yasbeck Haddad. Christian-Muslim Encounters. Jacksonville: University Press of Florida, 1995.

Scott, James C. Seeing Like a State, How Certain Scheme to Improve Human Condition have Failed. New Haven and London: Yale University Press, 1998.

Steenbrink, Karel A. Beberapa Aspek tentang Islam di Indonesia Abad ke-19. Jakarta: Bulan Bintang, 1984.

Steenbrink, Karel. Pesantren, Madrasah, Sekolah. Jakarta: LP3ES, 1986.

Wahid, Abdurrahman. "Massa Islam dalam Kehidupan Bernegara dan Berbangsa," Prisma. Extra Edition (1984): pp. 3-9.

\section{Electronic Sources}

http:// www.majelis.mujahidin.or.id

http://salafy.cjb.net/

http:/ /www.hidayatullah.com/

http://www.islamlib.com

http://www.pk-sejahtera.org

http://www.sabili.co.id/

http://www.tempointeraktif.com/hg/narasi/2004/04/17/nrs,200404 17-02,id.html.

Khan, Muqtadir. Is Muslim Wakeup; Undermining the Progressive Muslim Movement? http://www.ijtihad.org/Muslimwakeup.htm. 
Riza Sihbudi, in http://www.republika.co.id/kolom_detail.asp?id=184149\&kat_id=16

\section{Newspapers}

The Jakarta Post, July 30, 2005.

Kompas, November 18, 2002.

Rachman, Budhi Munawar. "Cak Nur dalam Ijtihad Paramadina." Gatra, No. 43 (September 5, 2005).

Bisri, A. Mustofa. "Menyegarkan Kembali Sikap Islam; Beberapa Kesalahan Ulil Abshar-Abdalla," Kompas, December 4, 2002.

Christanty, Linda. "Is There a Rainbow in Islam," Latitude Magazine, July 30, 2003. 